NAVA BAR, ARIE KIZEL University of Haifa, Israel

\title{
On the continuum from mainstreaming to inclusion: the development of the approaches towards students with special needs and their expression in the educational frameworks in Israel
}

\begin{abstract}
Nava Bar, Arie Kizel, On the continuum from mainstreaming to inclusion: the development of the approaches towards students with special needs and their expression in the educational frameworks in Israel [Spektrum - nurt główny - integracja: ewolucja podejść do studentów niepełnosprawnych i możliwości ich wyrażania się w strukturze edukacyjnej w Izraelu]. Interdyscyplinarne Konteksty Pedagogiki Specjalnej, nr 11, Poznań 2015. Pp. 163-187. Adam Mickiewicz University Press. ISSN 2300-391X
\end{abstract}

The State of Israel, like other developed countries around the world, engages intensively in the thinking about and care of students with special needs (SwSN). Israel attempts to open rang of possibilities to this population in its considerable diversity, while responding to the challenges faced by the population of students defined in Israel as „special education”.

This article presents the developing approaches, which are at the basis of the special educational system in Israel, as a case study of the reference to SwSn. The first part of the article presents the ideological elements of the special education system in Israel throughout its historical development, and the second part presents the way in which the continuum of the educational frameworks was understood to serve the educational perception.

KEY WORDS: Special education in Israel, Students with Special Needs, Continuum of Special Education Frameworks 


\section{The process from separation to mainstreaming and inclusion}

Already during the first decade after the establishment of the State of Israel (1948), the topic of special education rose to the educational agenda. Israel decided in its definition that it is the "nation of the Jewish people", which would emphasize education as consolidate the nation in the framework of the project of the "Nation Building". This historic decision brought with it the decision to separate the state educational system into a number of sectors: the Jewish state sector (which was defined as a the main sector), the religious Jewish state sector, the Arab state sector, the Druze, Circassian, and Bedouin state sectors, and the independent UltraOrthodox sector.

Simultaneously with these decisions, which were cardinal, a public discussion began and a policy was formed on the topic of the education of SwSN. The perception that was customary in this period and that lasted until the 1970s was that the school of special education has clear advantages over another framework and in this school the best treatment for SwSN is provided 1 . In this period there was a rise in the number of special education schools in Israel ${ }^{2}$. The reference to the SwSN was by categories, and the type of disorder defined the type of treatment. The teaching methods focused on the instruction of the study material at a slow pace, with the use of many means of illustration, without the adjustment of the contents to the learners' age $^{3}$. The guiding concept was the perception of separateness, which was translated into a special education system

${ }^{1}$ G. Avissar, T. Bab, Processes and trends in the planning of the studies in Israel for students with disabilities, Theory and Practice in the Planning of the Studies, 2010, 21.

${ }^{2} \mathrm{H}$. Ronen, Inclusion: Issues and disputes, [in:] Inclusiveness: Learners with disabilities in education, eds S. Reiter, Y. Leyser, G. Avissar, AHVA Publishers, Haifa, 2007.

3 S. Reiter, 'Normalize' the Integration, [in:] Inclusiveness: Learners with disabilities in education, eds S. Reiter, Y. Leyser, G. Avissar, AHVA Publishers, Haifa, 2007; H. Ronen, Inclusion: Issues and disputes. 
with an independent status that acts separately from general education ${ }^{4}$.

The first objection to the perception of separateness began in the 1970s, when a different approach developed, called „normalization", which placed at its center the right of the individual in society, including the individual with special needs, to a normal lifestyle ${ }^{5}$. According to this perception, people with disabilities have the right to live under conditions that are as similar as possible to the life conditions of people without disabilities. It is necessary to educate the members of society to accept people with disabilities among them and not to see them as a marginal group ${ }^{6}$ with all the concomitant negative implications.

On the background of this perception, in Israel, like in the Western World, began to grow a movement that called for inclusion and has based itself upon the humanistic philosophical perception, which sees SwSN to be equal in rights to the student who is not disabled. Consequently, the perception was adopted. Accordingly, the basic right of SwSN is to learn together with their peers, members of the same age group, in one educational system ${ }^{7}$. The proponents of this approach maintained that the inclusion will contribute to the promotion of two positive processes. On the one hand, it will support the acceptance of those with special needs into general society and on the other hand, it will help the "regular" students know that in society there are also those with special needs and therefore it is necessary to accept them.

At the basis of this perception was the idea of inclusion, which is established, on the fact that all members of society will understand

${ }^{4}$ M. Marom, K. Bar-Simon Tov, A. Kron, P. Koren, Inclusion of special needs children in the regular educational system: A review of the literature, The Center for the Research of Social Policy in Israel Press, Jerusalem, 2006.

${ }^{5} \mathrm{~B}$. Nirje, The basis and logic of the normalization principle, Australia and New Zealand Journal of Developmental Disabilities, 1985, 11(2).

6 Ibidem

${ }^{7} \mathrm{G}$. Avissar, Inclusion and accessibility: Curriculum planning and implementation for students with disabilities, Mofet Institute, Tel Aviv, 2010; M. Marom et al., Inclusion of special needs children in the regular educational system. 
that there is a continuum and a range of people, when each one of them has a basic right not only for existence but also for a place, for presence, for expression. Thus, the principle of equality will be realized, in practice, and will change from formal to essential ${ }^{8}$.

The Israeli educational system has been found for a number of years in a gradual process of implementation of a process that we suggest to call on the continuum from mainstreaming to inclusion. Namely a process that combines the assimilation of the approach that sees main importance in the inclusion of the SwSN in the school environment alongside the development of unique adjusted educational frameworks.

An important milestone of the inclusion movement was the Salamanca Statement (1994). At the end of the international conference in Spain, the decision was made, as phrased in the following statement:

Regular schools with this inclusive orientation are the most effective means of combating discriminatory attitudes, creating welcoming communities, building an inclusive society and achieving education for all; moreover, they provide an effective education to the majority of children and improve the efficiency and ultimately the cost-effectiveness of the entire education system ${ }^{9}$.

Two main approaches of inclusion developed: the mainstreaming/integration approach and the full inclusion approach. These approaches were based on a different interpretation of a principle that developed with the discussion about the inclusion of the SwSN in the regular environment, i.e. the principle of the Least Restrictive Environment (LRE).

According to the mainstreaming approach, it is necessary to place SwSN in a framework that will limit their development, quali-

${ }^{8}$ Y. Harpaz, Every Student Is a Student with Special Needs (Interview with Prof. Shunit Reiter) Hed Hahinuch (Echo of Education), 2013, 87(6), p. 44.

${ }^{9}$ UNESCO - United Nations Educational, Scientific and Cultural Organization, The Salamanaca Statement on principles, policy, and practice in special education and framework of action in the field of special education. Salamanaca, Spain, 1994, p. IX. 
ty of life, and achievement of objectives and goals set for their education to the least possible extent ${ }^{10}$. For this, it is necessary to create a continuum of educational frameworks that will provide an adequate solution for the needs of the diverse population of SwSN.

According to the full inclusion approach, it is necessary to eliminate the separate frameworks that cause discrimination and lack of equality and to adjust the regular framework to the widest variety of students, whether or not they have disabilities ${ }^{11}$.

From the 1990s, the mainstreaming approach (and not the full inclusion approach) is being implemented in the Israeli educational system, and thus in the special education system. It calls for the existence of a continuum of frameworks, which this article will discuss in the second part.

The special education system in Israel, which underwent a developmental process, is found today on the continuum that we suggest to call in this article from mainstreaming to inclusion. This continuum is based in Israel on the assumption that the SwSN population is diverse in terms of the types and severity of disabilities and in terms of the child's needs. Therefore, as the framework is more separate, the services given there to the student will be more comprehensive and will provide more adequate solutions for students with more severe and complex disabilities. During this period we can observe the first signs of the inclusion approach which perceives the otherness of the SwSN in a natural way.

The continuum of educational frameworks for SwSN ranges from the school of special education, the special class in the general school, and inclusion in the regular class. The guiding principle during the placement is the suitability to an environment that will least limit the child's development and this only after the severity of

${ }^{10}$ J.B. Crockett, J.M. Kauffman, The least restrictive environment. Lawrence Erlbaum, New Jersey, 1999; P. Howard, The Least Restrictive Environment: How to tell Journal of Law \& Education, 2004, 33.

${ }^{11}$ P. Mittler, Working towards inclusive education social contexts. David Fulton Publishers, London, 2000; W. Stainback, S. Stainback, eds, Controversial issues confronting special education, Allyn \& Bacon, Boston, 1996. 
the disability, despite the assistance and services provided to the child in the framework where he learns, does not allow him to be provided with satisfactory education ${ }^{12}$. This approach, which is implemented in Israel, is supported by the Quality of Life (QOL) concept, which developed during the past two decades and constitutes a redefinition of the principle of normalization ${ }^{13}$. This concept addresses the degree of fit between the individual's needs and the environmental conditions, according to which it is not enough to strive to integrate the individual in a more normative framework, rather is it necessary to allow him/her an environment that enables $\mathrm{him} /$ her to express his/her values, aspirations, and choices ${ }^{14}$.

\section{The first milestone: The Special Education Law}

The first milestone of the development of the recognition of the rights of SwSN was the legislation of the Special Education Law in Israel on July $12,1988^{15}$. The goal of the law is to protect the rights of SwSN in the educational system and to give these rights legal validity. In addition to express the commitment of the educational system, as representing society, towards SwSN from age 3 to age 21, who have a variety of needs and who have physical, mental, intellectual, or behavioral disabilities.

The law determined special education as a right and therefore as a civic entitlement ${ }^{16}$. By this entitlement, special education sought to

${ }^{12} \mathrm{H}$. Ronen, Inclusion: Issues and disputes.

${ }^{13}$ S. Reiter, R.L. Schalock, Applying the concept of Quality of Life in Israeli special education programs: A national curriculum for enhanced autonomy in students with special needs, International Journal of Rehabilitation Research, 2008, 31(1).

${ }^{14}$ S. Reiter, 'Normalize' the Integration; R.L. Schalock, Introduction and overview to the special issue on quality of life, Journal of Intellectual Disability Research, 2005, 10; R.L. Schalock, M.A. Verdugo Alonso, eds, Handbook on quality of life for human service practitioners. American Association on Mental Retardation, Washington, DC, 2002.

${ }^{15}$ The Special Education Law, 5748, State of Israel, 1988.

${ }^{16}$ N. Blass, A. Laor, Special education in Israel and the policy of inclusion. The Center for the Research of Social Policy in Israel Press, Jerusalem, 2002; D. Neon, 
establish a situation in which the SwSN, on the one hand, will enjoy systemic learning-teaching processes alongside a series of treatments and services adjusted to their special needs and on the other hand, will integrate into the regular system as equals. The law, therefore, includes both content in the field of the civic rights and a special and unique spirit that seeks to determine social norms. Above all, the law determined precedence and advance preference of the general educational system over the special education system ${ }^{17}$, assuming that SwSN who will be integrated as much as possible in general education will be ready for full integration in society outside of the areas of the school. As stated in the law (article 2): "The goal of special education... to facilitate the inclusion in it and in the work force"18. The law extended the right of the parents in the making of the decisions regarding the placement of their children, the preparation of the individual education plan for their child, and the involvement in the educational process in general ${ }^{19}$.

The practical translation of the law included two trends. The first trend was the transition of learning disabled students from separate schools of special education to classes defined as "special" in the schools of general education. The second trend was the transition of students from the "special" classes in the general education schools to the regular classes, while providing different types of assistance to these students so as to enable their inclusion.

These two trends illustrated in practice that over the years the approach was assimilated not only philosophically but also practically in the educational field. The students with severe difficulties

M. Milshtein, M. Marom, Integration of children with special needs in the elementary schools: Follow up after the implementation of the 'Book of Inclusion' in the Special Education Law. The Center for the Research of Disabilities and Employment of Special Populations, Jerusalem, 2012.

${ }_{17}$ M. Marom et al., Inclusion of special needs children in the regular educational system.

18 The Special Education Law 5762 (Amendment No. 7), State of Israel, 2002.

${ }^{19}$ C. Igel, S. Malichi, Special Education Law - Social, value-oriented, and professional reflection in the shaping of policy, [in:] Inclusiveness: Learners with disabilities in education, eds S. Reiter, Y. Leyser, G. Avissar, AHVA Publishers, Haifa, 2007; M. Marom et al., Inclusion of special needs children in the regular educational system. 
remained in the special schools ${ }^{20}$. The number of classes defined as "special" in the schools of general education steadily increased. This change, which was fundamental led, as every change does, to opposition, primarily among principals and teachers. The hours allotted for the inclusion of the students in the regular classes were few. The teachers in the regular classes did not know how to cope with children with disabilities. The research study of Reiter, Schanin, and Tirosh (1998) indicated that the teachers did not support the inclusion and preferred the opening of special education classes in their schools ${ }^{21}$.

The special classes in the general education school to which the inclusion students were transferred from the regular classes did not constitute a true solution for them. This issue awakened a professional and public opposition, which was expressed in the report of the State Comptroller:

The special classes, to which the lion's share of the hours was allotted... are the most significant and segregated framework of special education in the general education framework. This is the framework that creates the greatest opposition of the parents 22 .

\section{The second and the third milestone: Implementation committees and the "Inclusion Article"}

Since the legislation of the Special Education Law (1988), the implementation of inclusion in Israel has been examined. The sec-

${ }^{20}$ Margalit Committee, Report of the Committee for the Examination of the Realization of the Ability of Students with Learning Disabilities. Ministry of Education, Culture, and Sport, Department of Special Education, Jerusalem, 1997; D. Neon, M. Milshtein, M. Marom, Integration of children with special needs in the elementary schools.

${ }^{21}$ S. Reiter, M. Schanin, E. Tirosh, Israeli elementary school students' and teachers' attitudes towards mainstreaming children with disabilities, Special Services in the Schools, 1998, 13(1/2).

22 State Comptroller Report, The Coping of the Educational System with Special Needs Children. Annual Report Number 43, for the 1992 Years and Accounts for the Financial Year 1991, Office of the State Comptroller, Jerusalem, 1992, p. 298-308. 
ond milestone occurred during the1990s. In the year 1994, the masterplan for the implementation of the Special Education Law was constructed. Then, the Ministry of Education took upon itself the full commitment to the Special Education Law and its implementation $^{23}$. Later on two professional committees were established at the initiative of Ministers of Education and in response to public pressure - the Committee for the Examination of the Fulfillment of the Ability of Learning Disabled Students (Margalit Report, 1997)24, and the Committee for the Examination of the Implementation of the Special Education Law (Margalit Report, 2000)25.

The third milestone was followed the conclusions of the committees and the public discussion about the issue of the inclusion. This milestone indicates a main turning point in the aspiration for the full assimilation of the inclusion approach. It occurred in the year 2002, when it was decided to add the amendment to the Special Education Law, amendment 7 (B), called the „Inclusion Article"26. The main point of the amendment to the Special Education Law is the arrangement of the implementation of the inclusion of the SwSN in general education and primarily the anchoring of their rights and the services to be provided to them by law 27 .

In June 2003 this effort for the assimilation of the inclusion approach received support in the General Administration Circular

${ }^{23}$ G. Avissar, A. Moshe, P. Licht, "These are basic democratic values": The perceptions of policy makers in the Ministry of Education with regard to inclusion, [in:] Inclusiveness: From theory to practice, eds S. Reiter, G. Avissar, AHVA Publishers, Haifa, 2013; D. Neon, M. Milshtein, M. Marom, Integration of children with special needs in the elementary schools.

${ }^{24}$ Margalit Committee, Report of the Committee for the Examination of the Realization of the Ability of Students with Learning Disabilities.

${ }^{25}$ Margalit Committee, Report of the Committee for the Examination of the Implementation of the Special Education Law, Ministry of Education, Jerusalem, 2000.

26 The Special Education Law 5762 (Amendment No. 7), State of Israel, 2002.

${ }^{27}$ G. Avissar, Ts. Bab, Processes and trends in the planning of the studies in Israel for students with disabilities; G. Avissar, A. Moshe, P. Licht, "These are basic democratic values"; D. Neon, M. Milshtein, M. Marom, Integration of children with special needs in the elementary schools. 
of the Ministry of Education (10/B), in which there is a statement that obligates the new objectives of general education to constitute a supra-framework that supports SwSN. It is stated in the Circular that:

One of the touchstones of the educational system in Israel is its ability and willingness to provide an appropriate educational-scholastic solution for the special needs of students who find it difficult to adjust in scholastic or social terms to the norms accepted in the general education framework, and to avoid, to the extent possible, their referral to the special education frameworks. There is no dispute that there are students with special needs who have significant complex and comprehensive problems in different areas of functioning that necessitate comprehensive multidisciplinary intervention for most of the days of the studies and they therefore need an special educational-remedial framework to them. These students, and only these, are intended for the frameworks of special education. Most of the students with special needs can fit into the framework of the regular class using the inclusion program and can derive benefit from this both scholastically and socially-emotionally ${ }^{28}$.

\section{The fourth milestone: "Money Follows the Child" according to parents' choice}

The fourth milestone that constitutes another turning point in the perception of special education in Israel was expressed in the conclusions of the Governmental Committee under the leadership of the retired Supreme Court Justice Dalia Dorner (2009). The Committee recommended commencing a pilot, which can be called revolutionary, in the Israeli educational system. In this framework two changes would be performed. The first change is that all parents of SwSN can choose the framework in which their child will

${ }^{28}$ Circular of the Director General: The Mainstreaming program in the general education frameworks - For dealing with students with special needs who learn in the regular classes and in the special education classes, Ministry of Education, Jerusalem, June 1, 2003, 10(b). 
study. The second change is that the budget for the financing of the student's special needs will come with him to the school where he will learn. This change was called by the Dorner Committee the principle of the "Money Follows the Child" according to parents' choice. On this point, the Committee stated,

In the way that the budget of every child with special needs will be determined according to the characterization of his functioning and not only his disability and will be referred to the certain educational framework in which he and his parents chose that he would be educated ${ }^{29}$.

During the year 2012 the Israeli educational system advanced another step when the Ministry of Education decided to add the "Objective of Inclusion" to the eleven objectives of the strategic plan of the Ministry of Education. The objective of inclusion addresses the inclusion of students with scholastic, functioning and developmental difficulties in the general educational system and their promotion out of the aspiration to increase even further their ability of inclusion and to provide a variety of solutions to their needs before their referral to the inclusion committee ${ }^{30}$.

Examination of the implementation of the objective of inclusion reveals that, on the one hand, its importance from a systemic perspective lies in the very determination that it is necessary to integrate the students who have difficulties in general education. This step also indicates the adoption of the perception of inclusion in the general educational system and the determination of the responsi-

${ }^{29}$ Dorner Committee, Report of the Public Committee for the Examination of the Special Education System in Israel, Ministry of Education, Jerusalem, 2009, pp. 65-66.

${ }^{30}$ The Inclusion Committee is a school committee headed by the school principal. It determines, on the basis of an acceptable assessment, whether a student is entitled to be included in the inclusion program. A student who is included in the inclusion program is called an 'inclusion student' and the support given to him comes from the resources of special education.

Book of Inclusion: Clarification of the outlooks and implementation in the inclusion process, Ministry of Education, the Pedagogical Secretariat, Jerusalem, 2012. 
bility for SwSN, a responsibility perceived in the past primarily as the province of the people of special education. However, on the other hand, it is possible to see that the very determination that it is necessary to prevent the arrival of SwSN to special education is an inappropriate statement. The statement that special education is an inappropriate place and the general education is preferable (for those with difficulties as well), separates and labels special education and is contradictory to the spirit of inclusion, as perceived, for example, by Prof. Shunit Reiter from the Department of Special Education at the University of Haifa stated that,

Inclusion means the acceptance of others as they are, even if they are different from the norm; the reference to their disability is accepted, as one of the ways in which people are different from one another... people with disabilities want the recognition of their disabilities and not the "enlightened" denial of them or the "polite" ignoring of them ${ }^{31}$.

The data of more than a decade indicate that in Israel, like in the Western World, the number of SwSN who study in general education is steadily increasing. Thus, for example, according to the data of the Ministry of Education in the year 2001 a total of 1,656,607 students studied in the educational system in Israel, of whom 73,500 students are integrate in general education, of whom about 7,600 are students with difficult and complex disabilities. A total of 39,000 studied in separate frameworks ${ }^{32}$. A research document prepared for the Israeli Parliament in the year 2009 indicates that out of total of 1,848,864 students in Israel more than 80,000 SwSN received special education services within regular classes in the framework of the inclusion program and about 62,000 students learn in separate frameworks of special education ${ }^{33}$.

31 Y. Harpaz, Every Student Is a Student with Special Needs, p. 40.

$32 \mathrm{H}$. Ronen, Inclusion: Issues and disputes, p. 30.

${ }^{33}$ Y. Vorgan, Implementation of the 'Mainstreaming Law' in the 2010 school year. HaKnesset, Center of Research and Information, Jerusalem, 2009, p. 4. 
In the year 2013, out of total of 2,080,919 students in Israel, 117,000 students studied in the frameworks of inclusion in the general schools. 74,000 students studied in separate frameworks of special education in 1,554 special education kindergartens, 523 schools of special education, and 3,668 classes of special education in the regular schools ${ }^{34}$. These data indicate an increase in the number of inclusion students who study in the framework of general education but also an increase in the number of students who study in separate frameworks.

\section{Continuum of Frameworks of Special Education in Israel}

The perception of inclusions is expressed in the continuum of frameworks of special education in Israel. The term "continuum of frameworks" addresses the legitimization of the possibility of SwSN to integrate in a Least Restrictive Environment (LRE), the environment that least restricts their development, quality of life, and achievement of objectives and goals set for their education ${ }^{35}$, ranging from a separate framework to inclusion.

The perception is dynamic and is aimed at the possibilities of movement and transition between the existing frameworks ${ }^{36}$, so as to provide an appropriate solution for the needs of the diverse population of SwSN37. This population includes students with diverse learning disabilities, students with mental retardation who are found at different levels of functioning, students with emotional and behavioral disorders at different levels of severity, students on the autistic spectrum, students with mental disturbances, students with sensory disorders (deaf and hard of hearing students, blind

${ }^{34} \mathrm{~N}$. Dekel, Special education is an entitlement and not a punishment, Echo of Education, 2013, 87(6), p. 47.

${ }^{35}$ G. Avissar, A. Moshe, P. Licht, "These are basic democratic values".

${ }^{36} \mathrm{H}$. Ronen, Mental retardation: study, practices and teaching, Ach Publishers, Kiryat Bialik, 2005.

${ }^{37} \mathrm{H}$. Ronen, Inclusion: Issues and disputes. 
and visually impaired students), students with different difficult physical handicaps, and students who are developmentally delayed and language delayed ${ }^{38}$.

The continuum of frameworks is found on the range according to the degree of distance from general education: a segregated special education framework - a day or residential school for special education, a special education class in a general school, and a framework of inclusion in the regular class. In the separate schools of special education there are students whose disability is most severe, and the special education given to them is comprehensive, in-depth, and most intensive. As the framework is more integrating, the students' disabilities are less severe and the special education provided for them is more limited ${ }^{39}$. The policy of inclusion in Israel strives to reduce the number of SwSN who learn in separate frameworks and to increase the number of SwSN who learn in the more integrative frameworks.

The principles that lead the placement of the SwSN in the educational framework is determined according to the following principles: the preference for the more normative framework; the placement in the framework that least restricts the development; quality of life and achievement of the goals and objectives set for the education of the individual, and the transfer of the student to a separate framework only after all the possibilities have been realized. In this case, the student does not derive benefit from the framework in which he/she is found and only when it is clear that the separate framework will better meet his/her needs ${ }^{40}$.

The goal of the work process that exists in all the special education frameworks is derived from the Special Education Law (1988). It is to promote the students academically, socially, and emotionally

${ }^{38}$ R. Talmor, ,Educators' attitudes toward inclusion, [in:] Inclusiveness: Learners with disabilities in education, eds S. Reiter, Y. Leyser, G. Avissar, AHVA Publishers, Haifa, 2007.

${ }^{39} \mathrm{H}$. Ronen, Mental retardation: study, practices and teaching.

${ }^{40} \mathrm{H}$. Ronen, Inclusion: Issues and disputes. 
and to prepare them for their future lives as adults who fit into and participate in society and the community ${ }^{41}$.

The inclusion approach is expressed in each one of the frameworks, primarily through the construction of an individualized program for each SwSN and through the development of adjusted curricula ${ }^{42}$. The curricula in all the frameworks in which the SwSN are integrated, are adjusted to the continuum of the levels of functioning; to the principles of the Quality of Life that address the adjustments and changes that will enable the access of SwSN to the curricula and the participation in it; to personal support through an individualized program when the student is a partner in its preparation; the participation of the student in the community life from a young age and the development of an autonomous personality. As the level of the cognitive functioning of the students who learn in the frameworks of special education deviate from the norm, the number of adjustments and alternatives are greater relative to the members of the age group ${ }^{43}$. The work in the special education frameworks in Israel is based on a broad constellation of support of professionals who specialize in a variety of areas and who create in their joint work an interdisciplinary team ${ }^{44}$.

Although it was decided in Israel to implement the inclusion approach, a committee established in February 2000 for the examination of the implementation of the Special Education Law noted that: "Although it is possible to predict that the consistent decline in

41 The Special Education Law, 5748-1988, State of Israel.

42 P. Shavit, D. Tal, Teaching in an inclusive classroom: Contemporary trends and issues, [in:] Inclusiveness: From theory to practice, eds S. Reiter, G. Avissar, AHVA Publishers, Haifa, 2013.

${ }^{43}$ D. Tal, D. Leshem, Principles in the planning of the studies in special education: Abstract of the draft of the circular of the general director, planning the studies in the school of special education. Ministry of Education, the Department of Special Education, Jerusalem, 2007.

${ }^{44}$ I. Manor-Binyamini, Teamwork in interdisciplinary teams: Theory, research, and implementation, Ministry of Education, the Department of Special Education, Jerusalem, 2009. 
the number of students in schools of special education will continue, it is impossible to give up on them" 45 .

The special needs of the students led to the continuation of the existence of the schools of special education that are regional day schools or residential schools and the learners there are entitled to free education from the age of 3 to the age of 21. Every school has a main characteristic according to which SwSN are referred to it and their classes are homogeneous in terms of the classifications of their students' disabilities ${ }^{46}$.

However, there are considerable differences between the students in the same class, in the same grade and between the grades because of the difference in the students' functioning and the wide range of ages in the same school ${ }^{47}$. The SwSN who learn in the schools of special education have diverse problems, which are more severe and complicated, and need intensive special education that is multidisciplinary and comprehensive during most of the hours of the day ${ }^{48}$. These students include students with severe to moderate mental retardation, autism, students with severe behavioral and mental disabilities, students who have cerebral palsy, and students with complex learning disabilities ${ }^{49}$. To meet the objectives of the inclusion, as a guiding principle of the educational system, it was determined that the special education school will take care for frameworks of integration of SwSN in society and in the community.

Although the Special Education Law prefers placement in general education over special education, the schools of special education supply services that the students would not completely have if they were integrated in the framework of general education. This

${ }^{45}$ Margalit Committee, Report of the Committee for the Examination of the Implementation of the Special Education Law, p. 17.

${ }^{46}$ N. Blass, A. Laor, Special education in Israel and the policy of inclusion.

${ }^{47}$ D. Tal, D. Leshem, Principles in the planning of the studies in special education.

${ }^{48}$ Margalit Committee, Report of the Committee for the Examination of the Implementation of the Special Education Law; H. Ronen, Inclusion: Issues and disputes.

${ }^{49}$ Margalit Committee, Report of the Committee for the Examination of the Implementation of the Special Education Law. 
phrasing of the law reflected a contradiction that is expressed in the public discussion in Israel. The services for the special needs are a long study day, studies during the official vacations of the educational system, and services from teachers with specific and diverse specializations and experts from the paramedical professions, therapists in the emotional domain, and additional experts.

The service provided to these students in the special education school is through personal educational plans built by the interdisciplinary staff in the school and implemented in an individualized manner and in groups. Namely, with the adjustment of the curricula, teaching materials, and teaching methods and with the adjustment of the educational environment ${ }^{50}$.

The planning of the studies in the special education school includes an adjusted ",academic axis" (language education, mathematical education, information and communication technology, science and technology, civics, arts, and physical education) and a 'preparation for life' axis. The planning of the studies is according to the continuum of ages (for the most part, ages 6-21) and includes strategies for the connection between the personal learning plan built for each child and the class learning plan, so as to ensure the implementation of the personal plan. Additional subjects of study are included in the curriculum according to the characteristics of the population of students 51 .

On the continuum of the frameworks, the special education class in the school of general education is intended to provide the SwSN with three components: (1) an adjusted, special framework, (2) a framework that will allow the child to be found in the general school, and (3) a framework that will avert the child's separation from the general school and will encourage his integration among his peer group in diverse ways.

Students with mild mental retardation are referred to the special classes in the school of general education, students with learning

\footnotetext{
50 C. Igel, S. Malichi, Special Education Law; H. Ronen, Mental retardation.

51 D. Tal, D. Leshem, Principles in the planning of the studies in special education.
} 
disabilities of different levels of severity, students with emotional and behavioral disorders, ASD, and sensory disorders (deaf and hearing impaired students, blind and vision impaired students), and students with developmental delays and language delays. These students are entitled to paramedical treatments, treatments in the emotional field, psychological and educational services, and a special aide for the needy 52 . Every class has a main characterization according to which the SwSN are referred to the class ${ }^{53}$.

Like in the special education schools, in the special class in the general school the needs of SwSN are provided by learning in a class in which a small number of students learn and by a teacher who was trained for teaching special education. The teacher implements an individual approach for the class students, builds for every student an individualized educational plan that is implemented individually or in groups. In addition, the teacher adjusts the teaching methods, teaching materials, assessment methods, and the educational environment to the students' needs ${ }^{54}$.

The planning of the studies in the framework of the class for special education in the school of general education is based on the planning of the studies that aspires towards inclusion and therefore it is related to the age group in the school. The reliance on the curriculum of general education is intended to reduce gaps in the level of the achievements of the students who learn in the class of special education compared to the age group who learn in the class of general education and to enable the integration of those who are suitable in a number of subjects of study in the class of general education.

The model of educational work that integrates the SwSN from the special education class with those their age also occurs on a continuum:

52 D. Neon, M. Milshtein, M. Marom, Integration of children with special needs in the elementary schools.

${ }^{53} \mathrm{H}$. Ronen, Inclusion: Issues and disputes.

${ }^{54}$ C. Igel, S. Malichi, Special Education Law; H. Ronen, Inclusion: Issues and disputes. 
1. Local/minor inclusion according to which classes are found physically in the general school but because of severe behavior problems of the class students, there is minimal inclusion.

2. Inclusion of special education classes in events and projects in the school (ceremonies, trips, etc.).

3. Functional non-academic inclusion, according to which a number of students from the special class fit into nonscholastic activities in the parallel regular class in the school (sports, art, etc.).

4. Functional academic inclusion, or the scholastic inclusion of a student or a number of students from the special class in one or a number of study subjects ${ }^{55}$.

To enable the optimal realization of the principle of the continuum from mainstreaming to inclusion, in Israel there is a framework of inclusion that addresses the regular homeroom class in which the SwSN are integrated. This framework operates according to the model of full inclusion, according to which students with different functioning levels study in a shared scholastic space, with full partnership between SwSN and the peer group ${ }^{56 . "}$

About 90 percent of the SwSN who are integrated in general education in Israel have mild disabilities ${ }^{57}$. These students include students with learning disabilities, students with mild mental retardation, students with mild behavioral and emotional problems, students with attention deficit hyperactivity disorder, or language delayed students ${ }^{58}$. About 10 percent of the students who are integrated in the regular classes have moderate to severe disorders or complex problems ${ }^{59}$, including students with difficult mental retar-

${ }^{55} \mathrm{H}$. Ronen, Inclusion: Issues and disputes.

${ }^{56} \mathrm{M}$. Marom, et al., Inclusion of special needs children in the regular educational system; P. Shavit, D. Tal, Teaching in an inclusive classroom.

${ }^{57}$ Y. Vorgan, Implementation of the 'Mainstreaming Law'.

${ }_{58} \mathrm{O}$. Almog, Y. Leyser, Counselor role and interventions which facilitate the inclusion of students with special needs in general education, [in:] Inclusiveness: Education and society, eds S. Reiter, Y. Leyser, G. Avissar, AHVA Publishers, Haifa, 2011.

${ }^{59} \mathrm{Y}$. Vorgan, Implementation of the 'Mainstreaming Law'. 
dation, students with autism, and students with severe mental or behavioral disorders, students with sensory disorders (vision and hearing impairments), and students with physical handicap or health problems ${ }^{60}$. The inadequate allocation of support hours for the integrated students leads to the situation in which the children with severe and complex disabilities who are integrated in general education receive fewer hours of assistance, in comparison with children with similar disorders, at the same functioning level, who study in the special education framework ${ }^{61}$.

The discussion of the issue of the inclusion students is held within the school Inclusion Committee under the leadership of the school principal. According to the decisions of the Committee the entitlement of the students to a variety of types of support is determined: individualized or group teaching and support from the staff members who have training in special education, paramedical treatments, treatments in the emotional field, psychological and educational services, a special aide for the needy students, individualized learning plan, different learning aids, and adjustments in the curricula and in the ways of examination ${ }^{62}$.

The support given to the inclusion student includes additions to the regular curriculum. The main part of the teaching is held in the regular class by teachers who do not have training for special education 63 . The scope of the support given to the inclusion student (with the exception of those students entitled to an aide) is set in the discussions of the interdisciplinary staff of the school.

Most of the resources allotted to the inclusion students are for teaching and a small part is dedicated to paramedical treatment hours ${ }^{64}$. The mean of the support hours is about three weekly hours,

${ }^{60} \mathrm{O}$. Almog, Y. Leyser, Counselor role and interventions which facilitate the inclusion.

${ }^{61}$ D. Neon, M. Milshtein, M. Marom, Integration of children with special needs in the elementary schools.

62 Ibidem; The Special Education Law, Amendment No. 7.

${ }^{63} \mathrm{P}$. Shavit, D. Tal, Teaching in an inclusive classroom.

${ }^{64}$ N. Blass, A. Laor, Special education in Israel and the policy of inclusion. 
some with individualized support and some in the group framework. The support for the inclusion students is given in the homeroom class and in other frameworks outside of the homeroom class with additional students from the age group 65 .

In Israel there are two main models of the inclusion of SwSN in the general education system:

1. The inclusion of students with mild disabilities in the regular classes with the help of a special education teacher. These students are entitled to the help of a special education teacher that is performed in an individualized manner or in smaller learning groups, inside or outside of the class ${ }^{66}$.

2. Inclusive classes in which a number of SwSN (generally up to eight) study along with 'regular' students. In this class there are two teachers: a special education teacher and a general education teacher who determine together the curriculum. Some of the lessons are joint, and in some of the lessons the SwSN learn separately with the special education teacher ${ }^{67}$. The aspiration is to integrate the SwSN in all the theoretical subjects learned in the class, even if the learning material and the teaching method are different ${ }^{68}$.

The approach of on the continuum from mainstreaming to inclusion is expressed in that for every student, who is integrated in one of the two described models, an individualized educational plan is built adjusted to his needs and abilities. The individualized educational plan includes the adjustments (including adjustments in examination), the changes, and the alternatives required according to the needs of the student - his functioning, disability, and age and the support given to him, such as a teaching aide, devices, and

${ }^{65} \mathrm{M}$. Marom, et al., Inclusion of special needs children in the regular educational system; P. Shavit, D. Tal, Teaching in an inclusive classroom.

${ }^{66} \mathrm{R}$. Talmor, Educators' attitudes toward inclusion.

${ }^{67} \mathrm{M}$. Marom, et al., Inclusion of special needs children in the regular educational system; Ibidem.

${ }^{68} \mathrm{M}$. Marom, et al., Inclusion of special needs children in the regular educational system. 
unique aids. The student and his parents are partners in the process of the building and implementation of the individualized educational plan ${ }^{69}$.

The findings of research studies performed in Israel on the topic of inclusion present a picture similar to that in other countries (for example, Avissar, 2002; Avissar, Reiter, \& Leyser, 2003; Gavish \& Shimoni, 2006; Reiter, Schanin, \& Tirosh, 1998; Shechtman, Reiter, \& Schanin, 1993 $)^{70}$. The positions of the teachers of general education on the topic of inclusion are positive. The reservations and difficulties that the general education teachers bring up in the fulfillment of the idea of inclusion can indicate the difficulties that the inclusion teachers encounter in their work with them. The teachers of general education raise the need for the adjustment of the educational environment to inclusion, including: the allocation of appropriate time for cooperation, the preparation of a flexible system of hours, and the supply of appropriate help and budget to the inclusion student, physical adjustment of the learning environment, and inclusion of a number of students that is not too large in the class of 'regular' students and special needs students ${ }^{71}$.

\section{Bibliography}

Almog O., Leyser Y., Counselor role and interventions which facilitate the inclusion of students with special needs in general education, [in:] Inclusiveness: Education and

${ }^{69}$ D. Tal, D. Leshem, Principles in the planning of the studies in special education.

${ }^{70}$ G. Avissar, Teachers talk about inclusion: Current state, 1997-1999, Issues in Special Education and Rehabilitation, 2002, 17(1); G. Avissar, S. Reiter, Y. Leyser, Mainstreaming of exceptional students in general education: The school principal as an agent of change. Studies in Administration and Organization of Education, 2003, 27; B. Gavish, S. Shimoni, The perceptions of the teachers that include the inclusion of special needs students. Issues in Special Education and Rehabilitation, 2006, 21(1); S. Reiter, M. Schanin, E. Tirosh, Israeli elementary school students' and teachers' attitudes towards mainstreaming children with disabilities; Z. Shechtman, S. Reiter, M. Schanin, Intrinsic motivation of teachers and the challenge of mainstreaming: An empirical investigation. Special Services in the schools,1993, 7(1).

${ }^{71}$ R. Talmor, Educators' attitudes toward inclusion. 
society, eds S. Reiter, Y. Leyser, G. Avissar, AHVA Publishers, Haifa, 2011. [in Hebrew]

Avissar G., Teachers talk about inclusion: Current state, 1997 - 1999, Issues in Special Education and Rehabilitation, 2002, 17(1). [in Hebrew]

Avissar G., Inclusion and accessibility: Curriculum planning and implementation for students with disabilities, Mofet Institute, Tel Aviv, 2010. [in Hebrew]

Avissar G., Bab Ts., Processes and trends in the planning of the studies in Israel for students with disabilities, Theory and Practice in the Planning of the Studies, 2010, 21. [in Hebrew]

Avissar G., Moshe, A., Licht P., "These are basic democratic values": The perceptions of policy makers in the Ministry of Education with regard to inclusion [In:] Inclusiveness: From theory to practice, eds S. Reiter, G. Avissar, AHVA Publishers, Haifa, 2013. [in Hebrew]

Avissar G., Reiter S., Leyser Y., Mainstreaming of exceptional students in general education: The school principal as an agent of change. Studies in Administration and Organization of Education, 2003, 27. [in Hebrew]

Blass N., Laor A., Special education in Israel and the policy of inclusion. The Center for the Research of Social Policy in Israel Press, Jerusalem, 2002. [in Hebrew]

Book of Inclusion: Clarification of the outlooks and implementation in the inclusion process, Ministry of Education, the Pedagogical Secretariat, Jerusalem, 2012. [in Hebrew]

Circular of the Director General: The Mainstreaming program in the general education frameworks - For dealing with students with special needs who learn in the regular classes and in the special education classes, Ministry of Education, Jerusalem, June 1, 2003, 10(b). [in Hebrew]

Crockett J.B., Kauffman J.M., The least restrictive environment. Lawrence Erlbaum, New Jersey, 1999.

Dekel N., Special education is an entitlement and not a punishment, Echo of Education, 2013, 87(6). [in Hebrew]

Dorner Committee, Report of the Public Committee for the Examination of the Special Education System in Israel, Ministry of Education, Jerusalem, 2009. [in Hebrew]

Gavish B., Shimoni S., The perceptions of the teachers that include the inclusion of special needs students. Issues in Special Education and Rehabilitation, 2006, 21(1). [in Hebrew]

Harpaz Y., Every Student Is a Student with Special Needs, Hed Hahinuch, Echo of Education, 2013, 87(6). [in Hebrew].

Howard P., The Least Restrictive Environment: How to tell, Journal of Law \& Education, 2004, 33.

Igel C., Malichi S., Special Education Law - Social, value-oriented, and professional reflection in the shaping of policy, [in:] Inclusiveness: Learners with disabilities in education, eds S. Reiter, Y. Leyser, G. Avissar, AHVA Publishers, Haifa, 2007. [in Hebrew] 
Manor-Binyamini I, Teamwork in interdisciplinary teams: Theory, research, and implementation, Ministry of Education, the Department of Special Education, Jerusalem, 2009. [in Hebrew]

Margalit Committee, Report of the Committee for the Examination of the Realization of the Ability of Students with Learning Disabilities. Ministry of Education, Culture, and Sport, Department of Special Education, Jerusalem, 1997. [in Hebrew]

Margalit Committee, Report of the Committee for the Examination of the Implementation of the Special Education Law, Ministry of Education, Jerusalem, 2000. [in Hebrew]

Marom M., Bar-Simon Tov K., Kron A., Koren P., Inclusion of special needs children in the regular educational system: A review of the literature, The Center for the Research of Social Policy in Israel Press, Jerusalem, 2006. [in Hebrew]

Mittler P., Working towards inclusive education social contexts. David Fulton Publishers, London, 2000.

Neon D., Milshtein M., Marom M., Integration of children with special needs in the elementary schools: Follow up after the implementation of the 'Book of Inclusion' in the Special Education Law. The Center for the Research of Disabilities and Employment of Special Populations, Jerusalem, 2012. [in Hebrew]

Nirje B., The basis and logic of the normalization principle, Australia and New Zealand Journal of Developmental Disabilities, 1985, 11(2).

Reiter S., 'Normalize' the Integration, [in:] Inclusiveness: Learners with disabilities in education, eds S. Reiter, Y. Leyser, G. Avissar, AHVA Publishers, Haifa, 2007. [in Hebrew]

Reiter S., Schalock R.L., Applying the concept of Quality of Life in Israeli special education programs: A national curriculum for enhanced autonomy in students with special needs, International Journal of Rehabilitation Research, 2008, 31(1).

Reiter S., Schanin M., Tirosh E., Israeli elementary school students' and teachers' attitudes towards mainstreaming children with disabilities, Special Services in the Schools, 1998, 13(1/2).

Ronen H., Mental retardation: study, practices and teaching, Ach Publishers, Kiryat Bialik, 2005. [in Hebrew]

Ronen H., Inclusion: Issues and disputes, [In:] Inclusiveness: Learners with disabilities in education, eds S. Reiter, Y. Leyser, G. Avissar, AHVA Publishers, Haifa, 2007. [in Hebrew]

Schalock R.L., Introduction and overview to the special issue on quality of life, Journal of Intellectual Disability Research, 2005.

Schalock R.L., Verdugo Alonso M.A., eds, Handbook on quality of life for human service practitioners. American Association on Mental Retardation, Washington, DC, 2002.

Shavit P., Tal D., Teaching in an inclusive classroom: Contemporary trends and issues, [in:] Inclusiveness: From theory to practice, eds S. Reiter, G. Avissar, AHVA Publishers, Haifa, 2013. [in Hebrew] 
Shechtman Z., Reiter S., Schanin M., Intrinsic motivation of teachers and the challenge of mainstreaming: An empirical investigation, Special Services in the schools, 1993, 7(1). [in Hebrew]

The Special Education Law, 5748, State of Israel, 1988. [in Hebrew]

The Special Education Law 5762 (Amendment No. 7), State of Israel, 2002. [in Hebrew]

Stainback W., Stainback S., eds., Controversial issues confronting special education, Allyn \& Bacon, Boston, 1996.

State Comptroller Report, The Coping of the Educational System with Special Needs Children. Annual Report Number 43, for the 1992 Years and Accounts for the Financial Year 1991, Office of the State Comptroller, Jerusalem, 1992. [in Hebrew]

Tal D., Leshem D., Principles in the planning of the studies in special education: Abstract of the draft of the circular of the general director, planning the studies in the school of special education. Ministry of Education, the Department of Special Education, Jerusalem, 2007. [in Hebrew]

Talmor R., Educators' attitudes toward inclusion, [in:] Inclusiveness: Learners with disabilities in education, eds S. Reiter, Y. Leyser, G. Avissar, AHVA Publishers, Haifa, 2007. [in Hebrew]

UNESCO - United Nations Educational, Scientific and Cultural Organization, The Salamanaca Statement on principles, policy, and practice in special education and framework of action in the field of special education. Salamanaca, Spain, 1994.

Vorgan Y., Implementation of the 'Mainstreaming Law' in the 2010 school year. HaKnesset, Center of Research and Information, Jerusalem, 2009. [in Hebrew] 